\title{
Selected Nutrient Intakes of Free-Living White Children Ages 6-19 Years. The Lipid Research Clinics Program Prevalence Study ${ }^{(40,41)}$
}

\author{
KATHERINE M. SALZ, ISRAEL TAMIR, NANCY ERNST, PETER KWITEROVICH, \\ CHARLES GLUECK, BOBBE CHRISTENSEN, RHEA LARSEN, DIANE PIRHONEN, \\ T. ELAINE PREWITT, AND LYNNE W. SCOTT
}

\begin{abstract}
Departments of Pediatrics and Medicine, The Johns Hopkins University School of Medicine, Baltimore, Maryland, USA [K.M.S., P.K.]; Lipid Metabolism-Atherogenesis Branch, National Heart, Lung, and Blood Institute, National Institutes of Health, Bethesda, Maryland, USA [I.T., N.E.]; Department of Internal Medicine, University of Cincinnati College of Medicine, Cincinnati, Ohio USA [C.G., R.L.]; University of Texas School of Public Health, Houston, Texas USA [B.C.]; St. Michael's Hospital, Toronto, Ontario, Canada [D.P.]; Department of Biostatistics, University of North Carolina, Chapel Hill, North Carolina USA [T.E.P.]; and Baylor College of Medicine, FondrenBrown Bldg., Houston, Texas, USA [L.W.S.]
\end{abstract}

\begin{abstract}
Summary
We report energy intake and selected nutrient intakes-protein, fat (total, saturated, and polyunsaturated), carbohydrate (total, starch, and sucrose), and cholesterol-for 1251 white children ages 6-19 years. The data were obtained, by means of a 24-h dietary recall, from children who were randomly selected from the North American populations studied by the Lipid Research Clinics Program. Females $(N=584)$ consumed about $2000 \mathrm{kcal}$ daily, an intake that remained relatively constant throughout the age groups studied. Males $(N=667)$ had an energy intake of $2000 \mathrm{kcal} / \mathrm{day}$ during childhood that increased to over $3000 \mathrm{kcal} /$ day in adolescence. Energy sources for both sexes were approximately $15 \%$ protein, $38 \%$ total fat, $15 \%$ saturated fat, $6 \%$ polyunsaturated fat, $48 \%$ total carbohydrate, $19 \%$ starch, and $11 \%$ sucrose; cholesterol intake averaged about $145 \mathrm{mg} / 1000 \mathrm{kcal}$. For both sexes, fat intake increased with age. Compared to females, males ingested greater amounts of cholesterol and total and saturated fat.
\end{abstract}

\section{Abbreviations}

LRC, Lipid Research Clinics

PUF, polyunsaturated fatty acids

SF, saturated fatty acids

RDA, Recommended Dietary Allowances

$\mathrm{P} / \mathrm{S}$ ratio, ratio of polyunsaturated to saturated fatty acids

There is a growing consensus that the biochemical and anatomical precursors of atherosclerosis, as well as food habits, have their genesis in childhood $(9,17,22,28)$. Knowledge about nutrient intake in children is an important first step toward understanding the influence of diet on the atherosclerotic process that starts early in life. In this report, we examine the 24-h intake of selected nutrients by children ages 6-19 years, who constituted one-fourth of the individuals sampled in the North American Lipid Research Clinics (LRC) Prevalence Study.

The LRC Prevalence Study, conducted from 1972 to 1975, was designed to investigate the prevalence of the hyperlipoproteinemias in selected, free-living populations and to include assessment of certain variables, among them diet, that may influence plasma lipid and lipoprotein levels. The lipid and lipoprotein cholesterol levels of these children have been previously reported (36).

The purposes of this report: (1) to describe the intake by these children and adolescents of those nutrients that have been asso- ciated with plasma lipid and lipoprotein levels $(5,6,11,14,20,21$, $24,25,27,33,35$ ), and (2) to report age- and sex-associated differences in the dietary recall data as obtained during the second examination of the LRC Prevalence Study.

\section{MATERIALS AND METHODS}

Study populations. Of the seven LRCs that had a pediatric component, six clinics provided sufficient data on 6-19-year-old participants to be included here. Two of the clinic populations were school-based (Baylor and Cincinnati); two were householdbased (La Jolla and Minnesota); one was based on industrial employees (Toronto); and the other was based on enrollees of a prepaid medical plan in Columbia, Maryland (Johns Hopkins). In the latter two clinics, children of the propositus were included for study.

Of 11,173 white participants ages $6-19$ years, who were studied in the first LRC examination (Visit 1), 15\% were randomly recalled for a second more extensive evaluation (Visit 2). Of the 1649 eligible subjects, $85 \%$ participated in the Visit 2 study, after informed consent. (Although black children were also studied, this paper includes only the white participants; racial comparisons will be reported elsewhere.) The final numbers of subjects under 20 years of age are included in Tables 1-5.

Study design. The design of this cross-sectional study, including definitions of the target populations, sampling methods, standardization procedures, and data collection, has been previously reported (23).

Dietary methods. Dietary intake was assessed by means of the 24-h dietary recall. The period of time comprised the $24 \mathrm{~h}$ immediately before the 12 -h fast.

Twenty-four percent of the recalls were carried out on Mondays, which thus represents the food consumption pattern for Sunday. Although dietary data for Saturday were not obtained, the remaining days of the week were approximately equally distributed. These data represent our best approximation of what intake would be for an average day of the week.

The dietary interviews were conducted by registered dietitians centrally trained and certified to use standardized techniques for dietary data collection. Standard food models, e.g., plastic (NASCO, Ft. Atkinson, WI) and geometric models as well as standardized portions of nonperishable foods were used to facilitate the accuracy of reporting. The recalls were centrally coded at the Nutrition Coding Center in Minneapolis, Minnesota, and 
nutrient intake was computed at the Central Patient Registry and Coordinating Center at the University of North Carolina. (See Dennis et al. (7) for a complete description of the LRC dietary methods.)

Study participants reported their own food intake. This was done to assure comparability of the data collected from children and adults. Recognizing that many participants would not always be aware of fats used in food preparation and at the table, the LRC Program developed special coding rules to reflect commonly used home fats as well as a variety of commercial fats (7). Any supplementary information provided by parents or other meal providers is not included here, but will be examined in a separate publication.

The final data set includes only those dietary recalls judged as reliable by the interviewer. The training and certification program provided definitions to the dietitians for assessing reliability. The primary guideline for judging reliability was the ability of the participant to recall in sufficient detail the foods consumed. Unreliability occurred most often because of missing information, e.g., the participant was unable to recall one or more meals. Approximately $19 \%$ of recalls among 6-9-year-olds and 3\% of recalls from 10-19-year-olds were classified as unreliable. This rate compares to the $2 \%$ rated unreliable from the adult partici- pants, 20 years of age or older. Emmons and Hayes (8) have reported, however, that children in grades one through four are able to report their food intake accurately. Although in some instances, the participant judged the reported food intake to be considerably more or less than usual (atypical), these data were included because food intakes normally vary from day to day.

The subject of dietary intake methodology has been reviewed by both Marr (26) and Burk and Pao (3). Although the 24-h recall has drawbacks as a method for assessing individual nutrient intake, group data analysis is possible (16). Further, use of this technique has allowed comparison of LRC data with those of other large-scale dietary surveys that employed similar dietary methods $(32,37)$.

Data analysis. Dietary intake was computed for calories, protein, fat (total, saturated, and polyunsaturated), cholesterol and carbohydrate (total, starch, and sucrose). Although alcohol intake correlates with triglyceride and HDL cholesterol levels in adults (4) and children (29), it was not included in this nutrient analysis study because of the very small \% of the pediatric population ingesting alcohol and the limited amounts ingested.

Data for each nutrient are presented for males and females in the age groupings 6-9 years, 10-14 years, and 15-19 years, which roughly correspond to preadolescence, adolescence and postado-

Table 1. Intakes by children, 6-9 years of age

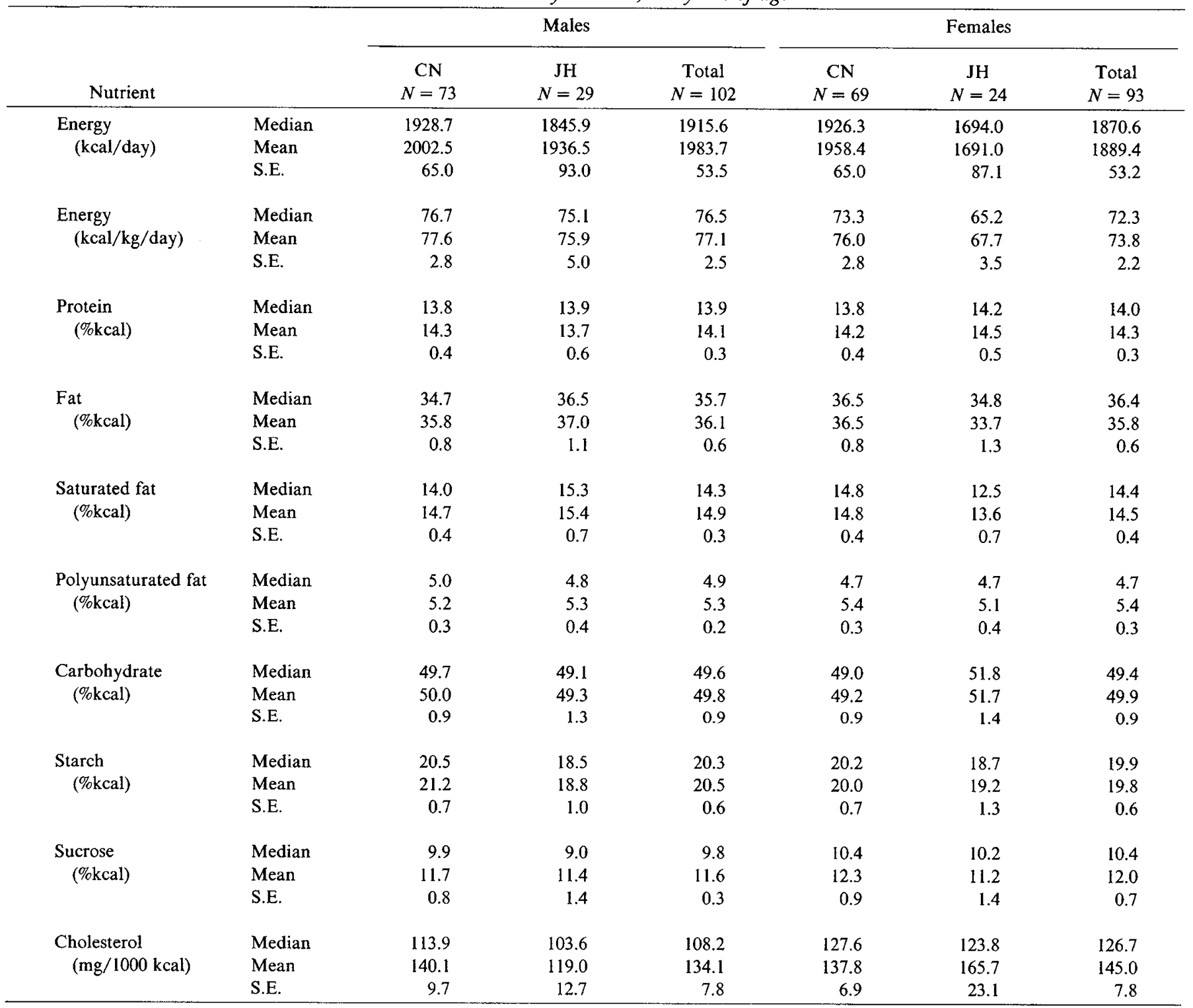

\footnotetext{
'Abbreviations: $\mathrm{CN}$, Cincinnati and JH, Johns Hopkins.
} 
lescence. Means and standard errors and medians were calculated (by standard formulas (1)) for each of these age/sex groupings. We adjusted the overall standard errors for clinic differences by weighting the measures of variability by sample size. Significant differences between selected age and sex groups were calculated by use of a two-sample $t$ test. In addition, the data were compared with those of the HANES (32) and USDA (37) surveys, which also used $24-\mathrm{h}$ dietary recalls.

\section{RESULTS}

The dietary intake data for 1251 participants ages 6-19 years seen at Visit 2 of the LRC Prevalence Study are presented by age, sex and clinic in Tables $1-5$. Total values for each age and sex group are described and discussed.

Energy intake. The energy intake for 6-9-year-old males (Table 1) was about $2000 \mathrm{kcal}$. Intake by 10-14-year-olds (Table 2) was significantly higher than that of the younger age group $(t=8.24$, $P<0.001$ ), and energy intake by the 15-19-year-olds (Table 4) was significantly greater than that of the 10-14-year-olds $(t=$ $6.68, P<0.001)$ at almost $3250 \mathrm{kcal} /$ day. The energy intake for females, however, peaked in the 10-14-year-old group (Table 3) at about $2200 \mathrm{kcal}$.

Table 2. Intakes by males, 10-14 years of age ${ }^{1}$

\begin{tabular}{|c|c|c|c|c|c|c|}
\hline Nutrient & & $\begin{array}{c}\mathrm{CN} \\
N=171\end{array}$ & $\begin{array}{c}\mathrm{JH} \\
N=36\end{array}$ & $\begin{array}{c}\text { MN } \\
N=45\end{array}$ & $\begin{array}{c}\text { TR } \\
N=26\end{array}$ & $\begin{array}{c}\text { Total } \\
N=278\end{array}$ \\
\hline \multirow{3}{*}{$\begin{array}{l}\text { Energy } \\
\quad(\text { kcal/day) }\end{array}$} & Median & 2439.8 & 2426.0 & 2760.0 & 2567.7 & 2502.7 \\
\hline & Mean & 2608.4 & 2478.5 & 2696.8 & 2764.6 & 2620.5 \\
\hline & S.E. & 71.1 & 116.8 & 113.5 & 206.5 & 53.4 \\
\hline \multirow{3}{*}{$\begin{array}{l}\text { Energy } \\
\quad(\mathrm{kcal} / \mathrm{kg} / \\
\text { day })\end{array}$} & Median & 55.6 & 59.4 & 65.0 & 61.6 & 59.0 \\
\hline & Mean & 60.4 & 60.5 & 66.0 & 64.1 & 61.7 \\
\hline & S.E. & 1.9 & 4.0 & 3.6 & 4.4 & 1.5 \\
\hline \multirow{3}{*}{$\begin{array}{l}\text { Protein } \\
\qquad(\% \text { kcal })\end{array}$} & Median & 14.1 & 13.3 & 14.2 & 15.3 & 14.2 \\
\hline & Mean & 14.6 & 14.1 & 14.8 & 16.0 & 14.7 \\
\hline & S.E. & 0.3 & 0.6 & 0.4 & 0.7 & 0.2 \\
\hline \multirow{3}{*}{$\begin{array}{l}\text { Fat } \\
\qquad(\% \mathrm{kcal})\end{array}$} & Median & 38.6 & 35.4 & 39.2 & 37.0 & 38.3 \\
\hline & Mean & 38.6 & 37.0 & 38.2 & 37.5 & 38.2 \\
\hline & S.E. & 0.5 & 1.1 & 0.8 & 1.4 & 0.4 \\
\hline \multirow{3}{*}{$\begin{array}{l}\text { Saturated fat } \\
\text { (\%kcal) }\end{array}$} & Median & 16.0 & 14.9 & 15.4 & 16.5 & 15.8 \\
\hline & Mean & 16.2 & 15.1 & 15.1 & 15.3 & 15.8 \\
\hline & S.E. & 0.3 & 0.6 & 0.4 & 0.7 & 0.2 \\
\hline \multirow{3}{*}{$\begin{array}{l}\text { Poly- } \\
\text { unsaturated fat } \\
\quad(\% \text { kcal })\end{array}$} & Median & 4.7 & 5.1 & 4.9 & 4.9 & 4.9 \\
\hline & Mean & 5.2 & 5.1 & 5.5 & 5.8 & 5.3 \\
\hline & S.E. & 0.2 & 0.3 & 0.4 & 0.5 & 0.1 \\
\hline \multirow{3}{*}{$\begin{array}{c}\text { Carbohydrate } \\
\text { (\%kcal) }\end{array}$} & Median & 46.6 & 49.2 & 46.3 & 45.9 & 46.9 \\
\hline & Mean & 46.8 & 48.9 & 47.0 & 46.5 & 47.0 \\
\hline & S.E. & 0.6 & 1.2 & 1.0 & 1.8 & 0.5 \\
\hline \multirow{3}{*}{$\begin{array}{l}\text { Starch } \\
\quad(\% \text { kcal })\end{array}$} & Median & 18.9 & 16.8 & 18.1 & 20.9 & 19.2 \\
\hline & Mean & 19.3 & 17.9 & 18.9 & 22.2 & 19.3 \\
\hline & S.E. & 0.5 & 1.1 & 0.8 & 1.6 & 0.4 \\
\hline \multirow{3}{*}{$\begin{array}{l}\text { Sucrose } \\
(\% \text { kcal })\end{array}$} & Median & 10.8 & 9.8 & 9.7 & 6.8 & 10.4 \\
\hline & Mean & 12.4 & 10.7 & 10.8 & 8.2 & 11.5 \\
\hline & S.E. & 0.6 & 1.0 & 1.0 & 1.2 & 0.4 \\
\hline \multirow{3}{*}{$\begin{array}{l}\text { Cholesterol } \\
\text { (mg/1000 } \\
\text { kcal) }\end{array}$} & Median & 127.0 & 121.2 & 119.3 & 110.3 & 122.0 \\
\hline & Mean & 152.1 & 148.8 & 136.3 & 152.0 & 149.1 \\
\hline & S.E. & 6.4 & 15.3 & 9.9 & 18.8 & 5.0 \\
\hline
\end{tabular}

' Abbreviations: CN, Cincinnati; JH, Johns Hopkins; MN, Minnesota; and TR, Toronto.
Table 3. Intakes by females, 10-14 years of age

\begin{tabular}{|c|c|c|c|c|c|c|}
\hline Nutrient & & $\begin{array}{c}\mathrm{CN} \\
N=148\end{array}$ & $\begin{array}{c}\mathrm{JH} \\
N=33 \\
\end{array}$ & $\begin{array}{c}\mathrm{MN} \\
N=26 \\
\end{array}$ & $\begin{array}{c}\text { TR } \\
N=21\end{array}$ & $\begin{array}{c}\text { Total } \\
N=228 \\
\end{array}$ \\
\hline \multirow{3}{*}{$\begin{array}{l}\text { Energy } \\
\quad(\text { kcal/day })\end{array}$} & Median & 1967.8 & 2021.4 & 2437.6 & 2110.4 & 2096.7 \\
\hline & Mean & 2147.8 & 2120.2 & 2521.4 & 2258.1 & 2196.6 \\
\hline & S.E. & 56.1 & 122.3 & 110.0 & 174.0 & 45.3 \\
\hline \multirow{3}{*}{$\begin{array}{l}\text { Energy } \\
\quad(\mathrm{kcal} / \mathrm{kg} / \\
\text { day })\end{array}$} & Median & 48.0 & 47.0 & 56.3 & 48.8 & 49.2 \\
\hline & Mean & 52.3 & 51.2 & 57.6 & 59.8 & 53.4 \\
\hline & S.E. & 1.6 & 3.5 & 4.0 & 5.5 & 1.4 \\
\hline \multirow{3}{*}{$\begin{array}{l}\text { Protein } \\
\quad(\% \mathrm{kcal})\end{array}$} & Median & 13.3 & 14.8 & 14.5 & 14.5 & 13.7 \\
\hline & Mean & 14.0 & 15.2 & 14.1 & 14.8 & 14.3 \\
\hline & S.E. & 0.3 & 0.6 & 0.5 & 0.8 & 0.2 \\
\hline \multirow{3}{*}{$\begin{array}{l}\text { Fat } \\
\qquad(\% \mathrm{kcal})\end{array}$} & Median & 37.0 & 37.4 & 37.3 & 37.4 & 37.3 \\
\hline & Mean & 37.3 & 38.8 & 37.0 & 37.0 & 37.5 \\
\hline & S.E. & 0.6 & 1.2 & 1.0 & 1.2 & 0.5 \\
\hline \multirow{3}{*}{$\begin{array}{l}\text { Saturated fat } \\
\text { (\%kcal) }\end{array}$} & Median & 14.7 & 16.4 & 13.3 & 15.5 & 14.9 \\
\hline & Mean & 14.8 & 16.1 & 14.2 & 15.1 & 14.9 \\
\hline & S.E. & 0.3 & 0.8 & 0.6 & 1.0 & 0.2 \\
\hline \multirow{3}{*}{$\begin{array}{l}\text { Poly- } \\
\text { unsaturated fat } \\
\quad(\% \text { kcal })\end{array}$} & Median & 5.3 & 5.5 & 5.7 & 5.1 & 5.3 \\
\hline & Mean & 5.7 & 5.7 & 5.9 & 5.9 & 5.8 \\
\hline & S.E. & 0.2 & 0.5 & 0.3 & 0.7 & 0.2 \\
\hline \multirow{3}{*}{$\begin{array}{l}\text { Carbohydrate } \\
\text { (\%kcal) }\end{array}$} & Median & 48.9 & 47.1 & 47.4 & 47.0 & 48.7 \\
\hline & Mean & 48.7 & 45.9 & 48.9 & 48.1 & 48.2 \\
\hline & S.E. & 0.7 & 1.6 & 1.2 & 1.8 & 0.5 \\
\hline \multirow{3}{*}{$\begin{array}{l}\text { Starch } \\
\quad(\% \mathrm{kcal})\end{array}$} & Median & 19.1 & 16.2 & 19.3 & 17.9 & 18.8 \\
\hline & Mean & 19.6 & 17.7 & 19.4 & 18.7 & 19.2 \\
\hline & S.E. & 0.5 & 1.2 & 1.0 & 1.0 & 0.4 \\
\hline \multirow{3}{*}{$\begin{array}{l}\text { Sucrose } \\
\quad(\% \text { kcal })\end{array}$} & Median & 11.5 & 8.4 & 10.2 & 8.6 & 10.9 \\
\hline & Mean & 12.1 & 9.7 & 11.5 & 10.5 & 11.5 \\
\hline & S.E. & 0.5 & 1.1 & 1.2 & 1.7 & 0.4 \\
\hline \multirow{3}{*}{$\begin{array}{l}\text { Cholesterol } \\
\text { (mg/1000 } \\
\text { kcal) }\end{array}$} & Median & 114.2 & 125.8 & 104.2 & 119.2 & 114.6 \\
\hline & Mean & 142.9 & 149.4 & 105.0 & 119.3 & 137.3 \\
\hline & S.E. & 7.9 & 17.1 & 5.6 & 8.8 & 5.8 \\
\hline
\end{tabular}

${ }^{1}$ Abbreviations: CN, Cincinnati; JH, Johns Hopkins; MN, Minnesota; and TR, Toronto.

Kilocalories per $\mathrm{kg}$ body weight was inversely related to age in both sexes. In males, the $77 \mathrm{kcal} / \mathrm{kg}$ at ages 6-9 years (Table 1) was significantly higher than the $62 \mathrm{kcal} / \mathrm{kg}$ of $10-14$-year-olds $(t=5.27, P<0.001)$ (Table 2 ), which was in turn significantly greater than the lowest male value of 51 in the 15-19-year-olds $(t$ $=6.22, P<0.001$ ) (Table 4). Similarly, in females, the $74 \mathrm{kcal} / \mathrm{kg}$ in 6-9-year-olds (Table 1) was significantly greater than the 53 $\mathrm{kcal} / \mathrm{kg}$ at ages $10-14$ years $(t=7.82, P<0.001$ ) (Table 3 ), which was in turn significantly higher than the lowest female value of 37 in the 15-19-year-olds $(t=10.18, P<0.001)$ (Table 5). Male intake of $\mathrm{kcal} / \mathrm{kg}$ was significantly higher than female intake for the 10-14-year-olds $(t=4.05, P<0.001)$ (Tables 2 and 3$)$ and 15-19-year-olds $(t=8.86, P<0.001)$ (Tables 4 and 5).

Protein, fat, and carbohydrate intakes. The three primary energyproducing nutrients, protein, fat, and carbohydrate, were also assessed by age and sex groupings.

In addition to having the largest energy intake, the 15-19-yearold males had the largest mean intake of protein (14.9\% of calories) (see Table 4). Protein intakes for females remained at about $14 \%$ of calories for each age group (Tables 1, 3, and 5).

The average fat intake was about $36 \%$ of calories for males and females ages 6-9 (Table 1). These fat intakes rose significantly to a high of $40 \%$ of calories for $15-19$-year-old males $(t=4.36, P<$ 
Table 4. Intakes by males, 15-19 years of age $e^{1}$

\begin{tabular}{|c|c|c|c|c|c|c|c|c|}
\hline Nutrient & & $\begin{array}{c}\mathrm{CN} \\
N=100\end{array}$ & $\begin{array}{c}\mathrm{JH} \\
N=22\end{array}$ & $\begin{array}{c}\mathrm{MN} \\
N=45\end{array}$ & $\begin{array}{c}\mathrm{TR} \\
N=20\end{array}$ & $\begin{array}{c}\mathrm{LJ} \\
N=20\end{array}$ & $\begin{array}{c}\text { BA } \\
N=80\end{array}$ & $\begin{array}{c}\text { Total } \\
N=287\end{array}$ \\
\hline \multirow{3}{*}{$\begin{array}{l}\text { Energy } \\
\text { (kcal/day) }\end{array}$} & Median & 3120.9 & 2485.9 & 3336.4 & 2753.0 & 3054.3 & 3114.6 & 3117.8 \\
\hline & Mean & 3183.6 & 2792.5 & 3792.3 & 2991.6 & 3489.5 & 3131.4 & 3242.5 \\
\hline & S.E. & 118.4 & 244.4 & 261.6 & $24 \overline{6} .5$ & 328.6 & 111.7 & 76.3 \\
\hline \multirow{3}{*}{$\begin{array}{l}\text { Energy } \\
\text { (kcal/kg/day) }\end{array}$} & Median & 49.3 & 43.3 & 51.3 & 41.0 & 49.5 & 49.4 & 49.3 \\
\hline & Mean & 50.4 & 42.1 & 58.4 & 46.2 & 56.1 & 48.3 & 50.5 \\
\hline & S.E. & 2.2 & 3.2 & 4.0 & 3.9 & 5.6 & 1.9 & 1.3 \\
\hline \multirow{3}{*}{$\begin{array}{l}\text { Protein } \\
\text { (\%kcal) }\end{array}$} & Median & 15.0 & 13.0 & 13.7 & 14.2 & 15.4 & 13.9 & 14.3 \\
\hline & Mean & 15.4 & 14.6 & 14.5 & 15.1 & 15.0 & 14.3 & 14.9 \\
\hline & S.E. & 0.4 & 1.2 & 0.5 & 0.8 & 0.8 & 0.4 & 0.2 \\
\hline \multirow{3}{*}{$\begin{array}{l}\text { Fat } \\
(\% \text { kcal })\end{array}$} & Median & 41.6 & 37.2 & 39.4 & 34.2 & 38.8 & 38.9 & 39.7 \\
\hline & Mean & 41.3 & 36.4 & 38.6 & 34.9 & 39.1 & 39.7 & 39.5 \\
\hline & S.E. & 0.7 & 1.7 & 1.3 & 2.1 & 1.4 & 0.9 & 0.5 \\
\hline \multirow{3}{*}{$\begin{array}{l}\text { Saturated fat } \\
\text { (\%kcal) }\end{array}$} & Median & 16.7 & 15.0 & 16.4 & 13.6 & 15.0 & 14.7 & 15.8 \\
\hline & Mean & 16.8 & 14.8 & 15.9 & 13.9 & 15.6 & 14.8 & 15.7 \\
\hline & S.E. & 0.4 & 0.8 & 0.6 & 0.9 & 0.9 & 0.4 & 0.2 \\
\hline \multirow{3}{*}{$\begin{array}{l}\text { Polyunsaturated fat } \\
\text { (\%kcal) }\end{array}$} & Median & 5.7 & 4.4 & 5.2 & 4.2 & 6.4 & 6.3 & 5.7 \\
\hline & Mean & 6.1 & 4.7 & 5.6 & 5.2 & 6.3 & 6.9 & 6.1 \\
\hline & S.E. & 0.3 & 0.4 & 0.3 & 0.7 & 0.5 & 0.3 & 0.2 \\
\hline \multirow{3}{*}{$\begin{array}{l}\text { Carbohydrate } \\
\text { (\%kcal) }\end{array}$} & Mean & 43.4 & 45.5 & 44.4 & 49.6 & 43.1 & 44.3 & 44.4 \\
\hline & Mean & 43.0 & 47.4 & 45.3 & 49.3 & 45.9 & 45.4 & 45.0 \\
\hline & S.E. & 0.8 & 2.2 & 1.2 & 2.3 & 1.7 & 1.1 & 0.5 \\
\hline \multirow{3}{*}{$\begin{array}{l}\text { Starch } \\
\text { (\%kcal) }\end{array}$} & Median & 16.9 & 14.0 & 17.2 & 18.5 & 18.7 & 18.8 & 17.6 \\
\hline & Mean & 17.7 & 16.0 & 17.3 & 21.1 & 17.6 & 18.7 & 18.0 \\
\hline & S.E. & 0.6 & 1.4 & 0.8 & 1.8 & 1.3 & 0.7 & 0.4 \\
\hline \multirow{3}{*}{$\begin{array}{l}\text { Sucrose } \\
\text { (\%kcal) }\end{array}$} & Median & 10.5 & 11.1 & 8.9 & 7.8 & 9.1 & 14.8 & 10.4 \\
\hline & Mean & 11.1 & 11.9 & 10.6 & 8.8 & 8.4 & 14.7 & 11.7 \\
\hline & S.E. & 0.7 & 1.8 & 1.1 & 1.4 & 1.2 & 1.0 & 0.5 \\
\hline \multirow{3}{*}{$\begin{array}{l}\text { Cholesterol } \\
(\mathrm{mg} / 1000 \mathrm{kcal})\end{array}$} & Median & 140.0 & 129.0 & 125.6 & 111.9 & 102.6 & 133.5 & 131.4 \\
\hline & Mean & 170.0 & 159.0 & 144.2 & 140.1 & 131.5 & 162.5 & 158.3 \\
\hline & S.E. & 9.7 & 21.3 & 10.9 & 23.1 & 21.5 & 10.7 & 5.5 \\
\hline
\end{tabular}

${ }^{1}$ Abbreviations: CN, Cincinnati; JH, Johns Hopkins; MN, Minnesota; TR, Toronto; LJ, La Jolla; and BA, Baylor.

0.001 ) (Table 4) and 39\% of calories for females of this age $(t=$ $3.72, P<0.001$ ) (Table 5).

The intake of fat was also calculated as \% of energy intake contributed by polyunsaturated fatty acids (PUF) and saturated fatty acids (SF). SF intake was about $15-16 \%$ of calories for males (Tables 1, 2, and 4) and just under $15 \%$ of calories for females (Tables 1, 3, and 5). Although no age-related patterns were discerned, there was a sex difference; males consumed significantly more SF than females among the 10-14-year-olds $(t=3.18, P<$ $0.005)$ (Tables 2 and 3$)$ and 15-19-year-olds $(t=2.83, P<0.005)$ (Tables 4 and 5). PUF intakes for both males and females were about $5 \%$ of calories at ages $6-9$ years (Table 1 ) and $6 \%$ of calories at ages 15-19 years (Tables 4 and 5).

Mean carbohydrate intake as a \% of total energy intake declined significantly with age, from a high at ages 6-9 years of $50 \%$ of calories for both males and females (Table 1), to a low at ages 15-19 years of $45 \%$ of calories for females $(t=5.65, P<0.001)$ (Table 5$)$ and $46 \%$ of calories for males $(t=4.56, P<0.001)$ (Table 4).

The carbohydrate intake was described further as the portion contributed by starch or sucrose. The starch intake declined significantly with age for both males $(t=3.47, P<0.001)$ and females $(t=2.92, P<0.001)$ from $20 \%$ of calories in 6-9-yearolds (Table 1) to $18 \%$ in 15-19-year-olds (Tables 4 and 5). The sucrose intake for females varied from $11.5 \%$ of calories in 10-14- year-olds (Table 3) to $13 \%$ of calories in 15-19-year-olds (Table $5)$. For males, the sucrose intake was about $11.5 \%$ of calories for all three age groups (Tables 1,2 , and 4).

Cholesterol intake. Mean cholesterol intake by males rose significantly with age from $134 \mathrm{mg} / 1000 \mathrm{kcal}$ in 6-9-year-olds (Table 1) to $158 \mathrm{mg} / 1000 \mathrm{kcal}$ in 15 -19-year-olds $(t=2.54, P<0.025)$ (Table 4). Cholesterol intake by females ranged from $137 \mathrm{mg} /$ $1000 \mathrm{kcal}$ at ages $10-14$ (Table 3) to $145 \mathrm{mg} / 1000 \mathrm{kcal}$ at ages 6-9 (Table 1). In the oldest age group males consumed significantly more cholesterol than females $(t=2.34, P<0.05)$ (Tables 4 and 5).

\section{DISCUSSION}

The dietary data gathered from children and adolescents in six of the North American LRCs show the general trends observed in previous nutrition surveys. For energy and the major nutrients, that is, protein, carbohydrate and fat, the LRC data can be compared with the HANES survey (32) and the USDA survey (37); they can also be examined in light of the recommendations of the Food and Nutrition Board of the National Research Council (13). For other nutrients, e.g., fatty acids, cholesterol, and starch, comparisons are limited to the few studies focusing on these nutrients in children $(14,18)$.

Energy. Males consumed more energy than females from ado- 
Table 5. Intakes by females, $15-19$ years of age ${ }^{1}$

\begin{tabular}{|c|c|c|c|c|c|c|c|}
\hline Nutrient & & $\begin{array}{c}\mathrm{CN} \\
N=105\end{array}$ & $\begin{array}{c}\mathrm{JH} \\
N=25\end{array}$ & $\begin{array}{c}\mathrm{MN} \\
N=40\end{array}$ & $\begin{array}{c}\mathrm{LJ} \\
N=20\end{array}$ & $\begin{array}{c}\text { BA } \\
N=73\end{array}$ & $\begin{array}{c}\text { Total } \\
N=263\end{array}$ \\
\hline \multirow{3}{*}{$\begin{array}{l}\text { Energy } \\
\text { (kcal/day) }\end{array}$} & Median & 1944.1 & 1821.5 & 1857.2 & 1563.4 & 1986.9 & 1937.0 \\
\hline & Mean & 2027.3 & 2089.2 & 1973.1 & 1821.8 & 2064.4 & 2019.6 \\
\hline & S.E. & 74.4 & 161.0 & 119.4 & 154.3 & 87.1 & 46.6 \\
\hline \multirow{3}{*}{$\begin{array}{l}\text { Energy } \\
\text { (kcal/kg/day) }\end{array}$} & Median & 34.7 & 31.3 & 32.7 & 27.2 & 37.0 & 34.5 \\
\hline & Mean & 36.3 & 38.4 & 34.3 & 32.5 & 38.6 & 36.5 \\
\hline & S.E. & 1.4 & 3.6 & 2.2 & 3.0 & 1.7 & 0.9 \\
\hline \multirow{3}{*}{$\begin{array}{l}\text { Protein } \\
\text { (\%kcal) }\end{array}$} & Median & 13.1 & 15.9 & 14.1 & 13.4 & 12.7 & 13.6 \\
\hline & Mean & 13.9 & 16.0 & 15.0 & 14.5 & 13.7 & 14.3 \\
\hline & S.E. & 0.4 & 0.7 & 0.8 & 0.7 & 0.5 & 0.3 \\
\hline \multirow{3}{*}{$\begin{array}{l}\text { Fat } \\
(\% \mathrm{kcal})\end{array}$} & Median & 37.8 & 40.4 & 36.3 & 41.6 & 38.7 & 38.6 \\
\hline & Mean & 38.2 & 39.4 & 38.2 & 41.2 & 38.7 & 38.7 \\
\hline & S.E. & 0.7 & 1.8 & 1.4 & 1.7 & 1.0 & 0.5 \\
\hline \multirow{3}{*}{$\begin{array}{l}\text { Saturated fat } \\
\text { (\%kcal) }\end{array}$} & Median & 15.4 & 15.1 & 13.6 & 14.8 & 14.5 & 14.8 \\
\hline & Mean & 15.2 & 15.5 & 14.6 & 15.1 & 14.5 & 14.9 \\
\hline & S.E. & 0.4 & 0.7 & 0.7 & 0.8 & 0.4 & 0.2 \\
\hline \multirow{3}{*}{$\begin{array}{l}\text { Polyunsaturated fat } \\
\text { (\%kcal) }\end{array}$} & Median & 5.8 & 6.3 & 5.0 & 6.0 & 6.3 & 6.0 \\
\hline & Mean & 6.1 & 6.5 & 5.8 & 7.5 & 6.9 & 6.4 \\
\hline & S.E. & 0.3 & 0.7 & 0.5 & 0.8 & 0.4 & 0.2 \\
\hline \multirow{3}{*}{$\begin{array}{l}\text { Carbohydrate } \\
\text { (\%kcal) }\end{array}$} & Median & 47.4 & 41.0 & 46.7 & 41.5 & 47.3 & 46.4 \\
\hline & Mean & 47.3 & 42.2 & 46.1 & 43.1 & 47.3 & 46.3 \\
\hline & S.E. & 0.8 & 1.4 & 1.6 & 1.8 & 1.0 & 0.5 \\
\hline \multirow{3}{*}{$\begin{array}{l}\text { Starch } \\
\text { (\%kcal) }\end{array}$} & Median & 18.4 & 13.3 & 16.2 & 13.8 & 18.6 & 17.2 \\
\hline & Mean & 18.8 & 14.8 & 16.2 & 14.0 & 19.1 & 17.7 \\
\hline & S.E. & 0.6 & 1.1 & 1.0 & 1.2 & 0.9 & 0.4 \\
\hline \multirow{3}{*}{$\begin{array}{l}\text { Sucrose } \\
(\% \mathrm{kcal})\end{array}$} & Median & 13.1 & 8.7 & 10.9 & 9.8 & 13.4 & 12.1 \\
\hline & Mean & 14.0 & 9.8 & 11.2 & 10.5 & 14.3 & 13.0 \\
\hline & S.E. & 0.8 & 1.5 & 0.9 & 1.5 & 1.0 & 0.5 \\
\hline \multirow{3}{*}{$\begin{array}{l}\text { Cholesterol } \\
(\mathrm{mg} / 1000 \mathrm{kcal})\end{array}$} & Median & 113.1 & 135.4 & 107.1 & 115.6 & 117.2 & 115.5 \\
\hline & Mean & 134.6 & 183.2 & 138.1 & 126.0 & 140.0 & 140.6 \\
\hline & S.E. & 7.3 & 25.7 & 15.0 & 13.3 & 9.3 & 5.2 \\
\hline
\end{tabular}

${ }^{1}$ Abbreviations: CN, Cincinnati; JH, Johns Hopkins; MN, Minnesota; LJ, La Jolla; and BA, Baylor.

lescence onward and had their peak intake later than females. Energy intake, expressed as $\mathrm{kcal} / \mathrm{kg}$ body weight, declined with age and intakes of males were consistently higher than those of females. The difference between male and female patterns of energy intake can be explained partly by differences in the growth patterns, the female growth rate slowing before that of the male $(10,38)$. Sex differences in physical activity possibly account for the remainder of the discrepancies (19).

In the younger age groups, energy intakes of the LRC population were generally similar to those of the HANES (32) and USDA (37) populations. Among the 15-19-year-olds, however, the LRC males consumed 7\% more calories than did HANES $(t$ $=5.03, P<0.001)$ and USDA males, and LRC females about $15 \%$ more than HANES females $(t=5.03, P<0.001)$. Because no measures of variability are readily available for the USDA studies, it is not possible to draw any statistical conclusions about LRCUSDA differences.

When we compared average energy intakes of the LRC Prevalence population with the 1980 Recommended Dietary Allowances (RDAs) (13), we found that the youngest LRC age group was considerably below the RDAs, but this discrepancy was not evident in the older age groups. Intakes for the 6-9-year-olds in the LRC study were 18-20\% lower than the RDAs for the similar age group (7-10-year-olds). But intakes for the LRC 10-14-yearolds were virtually identical to the RDAs for their age group (11-14 years): males, $2620 \mathrm{kcal}$ (versus $2700 \mathrm{kcal}$, RDA) and females, $2196 \mathrm{kcal}$ (versus $2200 \mathrm{kcal}$, RDA). In the oldest group, the 15-19-year-old LRC females reported about $4 \%$ fewer kcal, but the males $16 \%$ more than the RDAs for their age group (15-18-year-olds).

Protein. Protein intake in the LRC population remained remarkably constant at $14-15 \%$ of calories for both males and females throughout the age groups studied. The protein intakes calculated from the HANES (32) and USDA (37) studies showed similar values at around $15 \%$. The three studies indicate that the estimated protein intakes far exceed the 6-9\% calculated from the recommendations of the Food and Nutrition Board of the National Research Council (13).

Fat. Only limited data on fat intake can be found in the literature, especially for children $(14,18)$. In the LRC data, total fat intake as \% of calories rose significantly with age and males consumed slightly more than females.

In the USDA survey (37), fat intake varied similarly according to age and sex. The USDA values are $10-15 \%$ higher than those of the LRC. Statistical testing of the differences cannot be assessed (see discussion of energy differences).

Among the children studied by the LRC, SF intake held through the age groups at about $15-16 \%$ of calories. In the older age groups, however, males consumed slightly but significantly more than females. Comparison with relevant literature is limited to the Bogalusa Heart Study (14), which showed a similar saturated fat intake (16\%) in 10-year-olds in a biracial community in Louisiana. 
PUF intake in the LRC pediatric population appeared to increase slightly with age (from just over 5 to just over $6 \%$ of calories) and females consumed a slightly greater \% PUF than males. As with SF, the LRC results were consistent with the 5\% reported by Frank et al. (14) in 10-year-old children in the Bogalusa Heart Study.

Carbohydrate. The \% of calories as carbohydrate declined significantly with age in both males and females, males consuming slightly less than females. These age and sex trends are in agreement with the USDA figures, although the USDA tends to be about 5\% lower. The Bogalusa Heart Study (14) of 10-year-olds showed close agreement with the \% of carbohydrate calories reported by the LRC.

As with total carbohydrate, the intake of its starch component decreased with age, although sex differences were not apparent. The Bogalusa Heart Study (14) reported an intake of $17 \%$ of calories as starch by 10 -year-olds, as compared with about $19 \%$ in the LRC population.

Sucrose intake, in contrast to starch, was not related to age. But sucrose intake may have been underestimated because it included only refined sugar used at the table, in recipes, and in commercial products where sugar is the only sweetener. The degree of this underestimation could not be determined (12).

Cholesterol. When we examined cholesterol as $\mathrm{mg} / 1000 \mathrm{kcal}$, we found that intake by males rose significantly with age, whereas among females, 6-9-year-olds had the highest cholesterol intake. The oldest males also had a significantly greater intake than their female counterparts. The discrepancy between means and medians indicates a considerable variation in intake among individuals, and a skewing of the distribution toward higher values.

The Bogalusa Heart Study (14) reported that 10-year-olds consumed a mean of $150 \mathrm{mg} / 1000 \mathrm{kcal}$, which is similar to that reported by the LRC. An earlier report (1960) by Hard and Esselbaugh (18) showed cholesterol intakes by 15-16-year-olds in Washington of $250-280 \mathrm{mg} / 1000 \mathrm{kcal}$. The 1960 data were based on 7-day food records and are not directly comparable to dietary recall data; however, it has been reported that the dietary cholesterol intake has decreased in this time period (15).

This report from the LRC Prevalence Study has provided detailed data on the nutrient intakes of a large number of American children, from diverse socio-economic and geographic groups. The data may be useful as a form of historical "milepost" in the face of changing population morbidity and mortality from coronary heart disease (2) and apparent changes in the nutrient intake by the population groups of the North American continent (2). The studies reveal that overall, females have "better" nutrient habits than males during childhood and adolescence, ingesting less total fat as a \% of total calories, less saturated fat (and thus a higher $\mathrm{P} / \mathrm{S}$ ratio), and less cholesterol.

Finally, several studies $(30,31,34)$, but not all (39), have suggested that nutrient intake may play a small but important role relative to plasma levels of lipids and lipoproteins in children. As such, nutrients may have some importance relative to pediatric precursors of atherosclerosis.

\section{REFERENCES AND NOTES}

1. Barr, A. J., Goodnight, J. H., Sall, J. P., and Helwig, J. T.: User's guide to the statistical analysis system. Raleigh, NC: SAS Institute, Inc. (1976).

2. Beaglehole, R., LaRosa, J. C., Heiss, G., Davis, C. E., Williams, O. D., Tyroler, H. A., and Rifkind, B. M.: Serum cholesterol, diet and the decline in coronary heart disease mortality. Prev. Med., 8: 538 (1979)

3. Burk, M. C. and Pao, E. M.: Methodology for large scale surveys of household and individual diets. Home. Ec. Res. Rep. No. 40, ARS, USDA, (1976).

4. Castelli, W. P., Doyle, J. T., Gordon, T., Haynes, C. G., Hjortland, M. C., Hulley, S. B., Kagan, A., and Zukel, W. J.: Alcohol and blood lipids, the cooperative lipoprotein phenotyping study. Lancet, 2: 153 (1977).

5. Connor, W. E., Hodges, R. E., and Bleiler, R. E.: The serum lipids in men receiving high cholesterol and cholesterol-free diets. J. Clin. Invest., 40:894 (1961).

6. Connor, W. E., Stone, D. B., and Hodges, R. E.: The interrelated effects of dietary cholesterol and fat upon human serum lipid levels. J. Clin. Invest., 43: 1691 (1964).

7. Dennis, B., Ernst, N., Hjortland, M., Tillotson, J., and Grambsch, V.: The
NHLBI nutrition system. J. Am. Diet. Assoc., 77: 641 (1980).

8. Emmons, L and Hayes, M.: Accuracy of 24-hour recalls of young children. $\mathbf{J}$. Am. Diet. Assoc., 62: 409 (1973)

9. Enos, W. J., Beyer, J. C., and Holmes, F. H.: Pathogenesis of coronary heart disease in American soldiers killed in Korea. J. Am. Med. Assoc., 158: 912 (1955).

10. Eppright, E. S., Sidwell, V. D., and Swanson, P. P.: Nutritive value of the diets of Iowa school children. J. Nutr., 54: 371 (1954).

11. Erickson, B. A., Coots, R. H., Mattson, F. H., and Kligman, A. M.: The effect of partial hydrogenation of dietary fats, of the ratio of polyunsaturated to saturated fatty acids, and of dietary cholesterol upon plasma lipids in man. $J$. Clin. Invest., 43: 2017 (1964).

12. Ernst, N., Fisher, M., Smith, W., Gordon, T., Rifkind, B. M., Little, J. A., Mishkel, M. A., and Williams, O. D.: The association of plasma high-density lipoprotein cholesterol with dietary intake and alcohol consumption. The Lipid Research Clinics Program Prevalence Study. Circulation, 62: (suppl IV): 41 (1980).

13. Food and Nutrition Board. Recommended Dietary Allowances. National Research Council, National Academy of Sciences, 9th Edition (1980).

14. Frank, G. C., Berenson, G. S., and Webber, L. S.: Dietary studies and the relationship of diet to cardiovascular disease risk factor variables in 10-year old children-the Bogalusa Heart Study. Am. J. Clin. Nutr., 31: 328 (1978).

15. Friend, B., Page, L., and Marston, R.: Food consumption patterns in the United States: 1909-13 to 1976. In: R. I. Levy, B. M. Rifkind, B. H. Dennis, N. Ernst: Nutrition, Lipids and Coronary Heart Disease, pp. 490-522 (Raven Press, New York, 1979).

16. Garn, S. M., Larkin, F. A., and Cole, P. E.: The real problem with one-day diet records. Am. J. Clin. Nutr., 31: 1114 (1978).

17. Glueck, C. J., Fallat, R. W., and Tsang, R.: Hypercholesterolemia and hypertriglyceridemia in children. Am. J. Dis. Child., 128: 569 (1974).

18. Hard, M. M. and Esselbaugh, N. C.: Nutritional status of adolescent children. IV. Cholesterol relationships. Am. J. Clin. Nutr., 8: 346 (1960).

19. Heald, F. P., Daugela, M., and Brunschuyler, P.: Physiology of adolescence (continued). N. Engl. J. Med., 268: 243 (1963).

20. Kaufmann, N. A., Poznanski, R., Blondheim, S. H., and Stein, Y. Changes in serum lipid levels of hyperlipidemic patients following the feeding of starch, sucrose and glucose. Am. J. Clin. Nutr., 18: 261 (1966).

21. Keys, A., Anderson, J. T., and Grande, F.: Serum cholesterol response to changes in the diet. I. Iodine value of dietary fat versus 2 S-P. Metabolism, 14: 747 (1965).

22. Kwiterovich, P. O. and Salz, K.: Pediatric aspects of the diet heart hypothesis. In: J. Bond: J. Proceedings of an International Symposium on Infant and Childhood Feeding. p. 283-315 (Academic Press, New York, New York 1981).

23. The Lipid Research Clinics Program Epidemiology Committee: Plasma lipid distributions in selected North American populations: The Lipid Research Clinics Prevalence Study. Circulation, 60:427 (1979).

24. MacDonald, I. and Braithwaite, D. M.: The influence of dietary carbohydrates on the lipid pattern in serum and in adipose tissue. Clin. Sci., 27: 23 (1964).

25. Mann, J. I., Truswell, A. S., and Manning, E. B.: Effects on serum lipids of reducing dietary sucrose or starch for 22 weeks in normal men. S. Afr. Med. J., 46: 827 (1972).

26. Marr, J. W.: Individual Dietary Surveys: Purposes and Methods. World Rev. Nutr. Diet., 13: 105 (1971).

27. McGandy, R. B., Hegsted, D. M., and Myers, M. L.: Use of semisynthetic fats in determining effects of specific dietary fatty acids on serum lipids in man. Am. J. Clin. Nutr., 23: 1288 (1970).

28. McNamara, J., Molot, M. A., Stremple, J. F., and Cutting, R. T.: Coronary artery disease in combat casualties in Viet Nam. J. Am. Med. Assoc., 216: 1185 (1971).

29. Morrison, J. A., Kelly, K., Mellies, M., deGroot, I., Khoury, P., Gartside, P. S., and Glueck, C. J.: Cigarette smoking, alcohol intake and oral contraceptives: relationships to lipids and lipoproteins in adolescent school children. Metabolism, 28: 1166 (1979).

30. Morrison, J. A., Larsen, R., Glatfelter, L., Boggs, D., Burton, K., Smith, C., Kelly, K. Mellies, M. J., Khoury, P., and Glueck, C. J.: Nutrient intake: relationships with lipids and lipoproteins in 6-19 year old children-The Princeton School District Study. Metabolism, 29: 133 (1980).

31. Morrison, J. A., Larsen, R., Glatfelter, L., Boggs, D., Burton, K., Smith, C., Kelly, K., Mellies, M. J., Khoury, P., and Glueck, C. J.: Interrelationships between nutrient intake and plasma lipids and lipoproteins in school children aged 6 to 19: The Princeton School District Study. Pediatrics, 47: 727 (1980).

32. National Center for Health Statistics. Dietary Intake Findings, United States, 1971-1974, USDHEW, PHS, HRA, NCHS. (DHEW Publ No. (HRA) $77-$ 1647) (1977).

33. Nestel, P. J., Carroll, K. F., and Havenstein. N.: Plasma triglyceride response to carbohydrates, fats and caloric intake. Metabolism, 19: 1 (1970).

34. Rasanen, L., Wilska, M., Kantero, R., Nanto, V., Ahlstrom, A., and Hallman, N.: Nutrition survey of Finnish rural children. IV. Serum cholesterol values in relation to dietary variables. Am. J. Clin. Nutr., 31: 1050 (1978).

35. Shepherd, J Packard, C. J, Patsch, J. R, Gotto A. M and Taunton, O. D: Effects of dietary polyunsaturated and saturated fat on the properties of high density lipoproteins and the metabolism of apo A-1. J. Clin. Invest., 61: 1582 (1978).

36. Tamir I Glueck, C. J Christensen, B., Kwiterovich, P., and Rifkind, B. M: Lipid and lipoprotein distributions in white children ages 6-19 years. The Lipid Research Clinics Program Prevalence Study. J. Chron. Dis., 34: 27 (1981).

37. USDA Nationwide Food Consumption Survey, 48 States, Spring 1977 (Preliminary). Science and Education Administration, US Dept of Agriculture (1979). 
38. Vaughan, V. C.: Growth and development. In Vaughan, V. C., McKay, R. J., Behrman, R. E., eds. Nelson Textbook of Pediatrics, Philadelphia: Saunders, W. B. and Co., 34-35 (1979).

39. Weidman, W. H., Elveback, L. R., Nelson, R. A., Hodgson, P. A., and Ellefson, R. D.: Nutrient intake and serum cholesterol level in normal children 6 to 16 years of age. Pediatrics, 61: 354 (1978).

40. Requests for reprints should be addressed to: Basil M. Rifkind, M.D., Lipid Metabolism and Atherogenesis Branch, National Heart, Lung, and Blood Institute, NIH, Federal Building Room 40I, 7550 Wisconsin Avenue, Bethesda, Md. 20205.

41. This research was supported by National Heart, Lung, and Blood Institute contracts numbered: NO1-HV1-2160-L, NO1-HV2-2914-L, NO1-HV1-2158L, NO1-HV2-2915-L, NOl-HV2-2917-L, NO1-HV1-2157-L, NO1-HVI-2243$\mathrm{L}$ and NO1-HV6-294l-L.

Nutrition Analysis Executive Committee: Fred Mattson, Ph.D., Chairman; George Beaton, M.D.; Elizabeth Brewer, R.D.; Tavia Gordon; William Insull, M.D.; J. Alick Little, M.D.; Robert E. Shank, M.D.; H.A. Tyroler, M.D.; O. Dale Williams, Ph.D.; Nancy Ernst, M.S., R.D.; Marian Fisher, Ph.D.; and Basil M. Rifkind, M.D.

LRC Nutrition Committee: Fred Mattson, Ph.D., Chairman; Janice Henske, R.D.; Rhea Larsen, R.D.; Agnes Gordon Fry, R.D.; Linda Snetselaar, M.S., R.D.; Katherine Salz, M.S., R.D.; Eileen Taylor, R.D.; Elizabeth Brewer, R.D.; Katherine Moore, R.D.; Elizabeth Burrows, R.D.; Phyllis Ullman, R.D.; Susan Grimes, R.D.; Valerie McGuire, B.Sc.; Nancy Ernst, M.S., R.D.; and Virginia Keating, M.S., R.D.

LRC Epidemiology Committee: H.A. Tyroler, M.D., Chairman; Paul Anderson, Ph.D.; Elizabeth Barrett-Connor, M.D.; Mary Brockway, Ph.D.; Gary Chase, Ph.D.; Bobbe Christensen, Ph.D.; Michael Criqui, M.D.; Michael Davies, M.D;
Alexander Deev, Ph.D.; Ido deGroot, M.P.H.; Manning Feinleib, M.D.; Marian Fisher, Ph.D.; Igor Glasunov, M.D.; Gaetan Godin, M.S.; S.T. Halfon, M.D.; Robin Harris, M.P.H.; William Haskell, Ph.D.; Gerardo Heiss, M.D., Ph.D.; David

Hewitt, M.A.; Judith Hill, M.S.; Joanne Hoover, M.D.; Donald Hunninghake, M.D.; David Jacobs, Ph.D.; Kathe Kelly, B.S.; J. Alick Little, M.D.; Arden Mackenthun, Ph.D.; Irma Mebane, M.S.; J. Medalie, M.D.; Richard Mowery, M.S.P.H.; John Morrison, Ph.D.; John B. O'Sullivan, M.D.; Basil Rifkind, M.D. Carl Rubenstein, M.D.; William J. Schull, Ph.D.; Dimitri Shestov, M.D.; Israel Tamir, M.D.; Henry Taylor, Ph.D.; Pearl Van Natta, Ph.D.; Robert Wallace, M.D.; O. Dale Williams, Ph.D.

LRC Directors Committee: Francois Abboud, M.D.; Edwin Bierman, M.D.; Reagan Bradford, M.D., Ph.D.; Virgil Brown, M.D.; William Connor, M.D.; Gerald Cooper, M.D., Ph.D.; John Farquhar, M.D.; Ivan Frantz, M.D.; Charles Glueck, M.D.; Elena Gerasimova, M.D.; Antonio Gotto, M.D., Ph.D.; Victor Grambsch James Grizzle, Ph.D.; William Hazzard, M.D.; Donald B. Hunninghake, M.D.; Frank Ibbott, Ph.D.; William Insull, M.D.; Anatoli Klimov, M.D.; Robert Knopp, M.D.; Peter Kwiterovich, M.D.; John LaRosa, M.D.; Basil Rifkind, M.D.; J. Alick Little, M.D.; Fred Mattson, Ph.D.; Maurice Mishkel, M.D.; Gustav Schonfeld M.D.; Helmut Schrott, M.D.; Robert Shank, M.D.; Thomas Sheffield, M.D Yechezkiel Stein, M.D.; Daniel Steinberg, M.D.; George Steiner, M.D.; O. Dale Williams, Ph.D.

42. The authors wish to acknowledge the editorial assistance of Janet Bungay, the technical assistance of Karen Wishnow and the statistical advice of Gwen Waldman.

43. Received for publication November 12, 1981 .

44. Accepted for publication June I, 1982. 